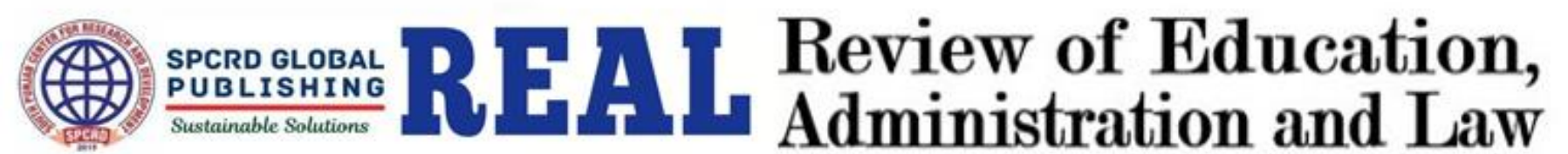 \\ Journal homepage: http://real.spcrd.org ISSN (Print): 2708-1788 ISSN (Online): 2708-3667
}

\section{The Effect of Teachers' Language Speaking Anxiety on their Performance in English}

\author{
a Tayyabba Yasmin, ${ }^{\mathrm{b}}$ Mubashar Nadeem, ${ }^{\mathrm{c}}$ Ghazal Khalid Siddique, ${ }^{\mathrm{d}}$ Muhammad Shahid Zulfiqar \\ Ali
}

${ }^{a}$ Lecturer, University of Education, Lahore, Pakistan

Email: tayyaba.yasmin@ue.edu.pk

${ }^{\mathrm{b}}$ Assistant Professor, University of Education, Lahore, Pakistan

Email: drnadeem@ue.edu.pk

${ }^{c}$ Assistant Professor University of Education, Lahore, Pakistan

Email: ghazlkhalid@ue.edu.pk

${ }^{\mathrm{d}}$ PhD Scholar, University of Education, Lahore, Pakistan

Email:shahidzac@yahoo.com

\begin{tabular}{l}
\hline ARTICLE DETAILS \\
\hline History: \\
Accepted o2 Sep 2020 \\
Available Online 30 Sep 2020 \\
\hline Keywords: \\
English Language, Anxiety, \\
Teachers' Performance, FGEI's \\
\hline JEL Classification: \\
A2O, I2O, P36 \\
\hline
\end{tabular}

DOI: $10.47067 /$ real.v3i2.63

\begin{abstract}
Communication is supposed to be important to convey the message to the audience. The communication skills of teachers occupied a major role in effective students' learning. If a teacher is anxious about speaking, his instructions may not be effective and also may affect the students' learning. The researchers were intended to measure the language anxiety of the teachers who teach in 1oth class while utilizing the survey method. The sample for the study included the teachers from Federal Government Educational Institutions (cants/ Garrisons) - FGEI's (C/G). The data regarding the teachers' language anxiety was collected by Teachers' Language Anxiety Scale adapted by the researcher from (Horwitz, Horwitz, \& Cope, 1986). The scale consists of 30 items with a Likert's Rating scale ranging from strongly agree to strongly disagree. In order to measure the teachers' performance, the cumulative GPA of their English subject that they have taught in recent anum was taken. This GPA was the outcome of their English teaching taken from Federal Board Intermediate \& Secondary Education annual exam. The results showed that there exists a negative, moderate as well as significant correlation between teachers' anxiety and their performance. It is recommended that the FDCI's should organize workshops on a regular basis for the teachers that focus on the practice of English speaking proficiency. There should be seminars propagating about the strategies to cope with language anxiety.
\end{abstract}

(C) 2020 The authors. Published by SPCRD Global Publishing. This is an open access article under the Creative Commons AttributionNonCommercial 4.0

Corresponding author's email address: tayyaba.yasmin@ue.edu.pk 


\section{Introduction}

Education is a process of developing individuals in such a way so they may become civilized citizens. It is the line by which the civilized and less civilized nations are separated. No nation can become successful unless attaining the goal of education (UNESCO, 2019). Nations' future is decided by the rate of their educated individuals. They are the means through the nation attains progress and prosperity. They increase the financial status of their country and make it a sovereign one (Zulfiqar, 2016).

There are individuals who educate individuals and induce their experiences and of the mankind in them. Those are the teachers who excel in their capabilities for the nation's education. They induce knowledge in students through communication as well as training (Asrar, Tariq, \& Rashid, 2018). The man has a distinction of verbal communication as compared to other living beings. The teachers also deploy it as a means to the successful end (Khan, Khan, Zia-Ul-Islam, \& Khan, 2017). The more a teacher is an effective communicator; the more the instructions will be done effectively (Khan \& Khan, 2017).

The teachers must be well versed with the communication skill so they could convey their stance at ease and effectively (Bee, 2012). The teacher has to convey the content matter and make students understand the lesson. The instructions can only be effective if they are communicated in an effective way (Loy, 2006). Effective communication is not only important for teaching, rather it has the necessity for classroom management as well (Ehindero, 2000; Khan, Khan, Zia-Ul-Islam, \& Khan, 2017). However, the ground reality shows that the teachers feel anxious when they are to teach the secondary language (Hismanoglu, 2013). Those who feel anxious while speaking, are led to language anxiety due to this difficulty of communication (Jawad \& Al-Obaydi, 2015; Alqahtani, 2019). If a teacher is anxious about speaking, his instructions may not be effective and also may affect the students' learning (Tepeh, 2016).

Language anxiety is said to be either fear or the hesitation one feels while speaking the language. One assumes that one cannot speak appropriately in the targeted language (Hismanoglu, 2013). It has been stated as an unpleasant emotion and complex linked with the speaking of usually secondary language (Alqahtani, 2019; Jawad \& Al-Obaydi, 2015). The anxiety has been further categorized into three as the trait which is linked to one's personality whereas the state is related to any specific state and situation-specific anxiety is concerned with a certain situation (Tuncer, 2015) \& (Tepeh, 2016).

Khan, Khan, Zia-Ul-Islam, \& Khan (2017), conducted research and concluded based on findings that teachers' performance has been influenced by their language speaking anxiety. On the other hand, Liu (2015) also studied the teachers' language anxiety and revealed that their performance is affected by their language anxiety. As far as the students' anxiety is concerned, the available literature is abundant. However, there is quite insufficient literature regarding the teachers' language anxiety. So, the present study has been done to fill in such a gap in the existing literature.

\section{Statement of the Problem}

Since the medium of instructions has been changed to English which is not our native language, so the students are required to learn the English language. However, they face many hurdles in this way of language acquisition. Language anxiety is an important one of them that affects the learning of the English language (Tuncer, 2015). Many studies have been conducted to investigate the relationship 
between students' language anxiety, motivation, and achievement. However, this study was conducted to investigate that either the teachers also feel language anxiety or only students become the victims of anxiety. In case, the teachers also feel language anxiety, then to what extent their anxiety has an impact on their performance. So, the objective of this study was to find out the effect of teachers' language anxiety on their performance.

\section{Significance of the study}

Language anxiety is considered to be a hurdle in the way of language acquisition and students achievement (MacIntyre \& Gregersen, 2012). Zaman (2017) argued that the language anxiety disturbs the students' learning of secondary language due to which they show poor performance in their academics. The students' poor performance depends upon the level of anxiety. The more anxious any student is, the more poor performance would be. Halder (2018) said that acquisition of English language has been challenging because the students' academic achievement is influenced by it whereas itself is affected by the students' language learning anxiety. Razak yassin \& Maasum (2017) stated that students' motivation to learn English language as well as their academic achievement is affected by the language anxiety. It is advocated by Hismanoglu (2013) that less anxious environment should be given to students so they could learn at ease. But if the teachers are anxious themselves, then the students' motivation and achievement may be affected. As Khan \& Khan (2017) stated that student' success and failure regarding academics are affected by their teachers' communication skills. Ferhat (2011) argued that there are many sources of students' language anxiety and low performance in their academics. The teachers' interaction is one of them.

If the teacher him/herself is anxious, it will affect the students' academic achievement too. There are a number of researches which investigate the students' language anxiety and its relationship with their academic achievement. However, there is no research related to the impact of or correlation between teachers' language anxiety and students' motivation to learn English language as well as their achievement. That's what the teachers' anxiety was investigated in this study to find out its impact on students' motivation and achievement. The results and recommendations of this study would be helpful for the teachers to decrease their language anxiety in order to increase students' motivation and achievement. This study was conducted while taking the sample of $10^{\text {th }}$ class students because the researcher is a teacher in a secondary school, so, the researcher was interested herself to conduct the research in school context. The students of $10^{\text {th }}$ class were taken as sample as the survey was done in this research, the students of $10^{\text {th }}$ class are assumed by the researcher to be enough mature to complete the questionnaire at ease. On the other hand, SSTs were included in the study because they teach at secondary level. So, as researchers were intended to measure the language anxiety of the teachers who teach in $10^{\text {th }}$ class, so the SSTs were selected as sample.

\section{Methodology}

The present study was quantitative in nature which was conducted while utilizing the survey method. The sample for the study included the teachers from Federal Government Educational Institutions (cants/ Garrisons) - FGEI's (C/G). There were total 480 English teachers (230 ESTs, 170 TGTs and 80 SSTs). The sample was selected while taking the 70\% individuals through the stratified sampling as 161 ESTs, 119 TGTs and 56 SSTs. The data regarding the teachers' language anxiety was collected by Teachers' Language Anxiety Scale adapted by the researcher from (Horwitz, Horwitz, \& Cope, 1986). The scale consists of 30 items with a Liker's Rating scale ranging from strongly agree to strongly disagree. The Cronbach's Alpha was applied to measure the reliability of the instrument, which was 0.71. In order to measure the teachers' performance, the cumulative GPA of their English subject that they have taught in recent anum was taken. This GPA was the outcome of 
their English teaching taken from Federal Board Intermediate \& Secondary Education annual exam.

\section{Analysis and Results}

Simple linear regression was utilized to predict the effect of teachers' anxiety on their performance after confirming the significant correlation between said variables. The details of the analysis are given below:

Table 1: Correlation between Teachers' Anxiety and Performance

\begin{tabular}{|l|l|l|}
\hline & Anxiety & Performance \\
\hline Anxiety & 1 & $-.428^{* *}$ \\
\hline Performance & & 1 \\
\hline
\end{tabular}

Correlation between teachers' anxiety and performance is identified with the help of Pearson $r$, whose results are presented in table 1 . The values of this table through light on the occurrence of negative, moderate as well as a significant correlation between teachers' anxiety and their performance, because $r=-.428, p<.001$. As $r$ values are less than .5 and greater than .2 , which indicate the moderate correlation, whereas the negative symbol specifies the inverse relationship between said variables. Based on this evidence null hypothesis is rejected.

Table 2: Effect of Teachers' Anxiety on Their Performance

\begin{tabular}{|l|l|l|l|l|l|}
\hline $\mathrm{R}$ & R Square & Adjusted R Square & $d f$ & $F$ & Sig. \\
\hline .428 & .183 & .181 & 1 & 74.933 & .000 \\
\hline
\end{tabular}

Simple linear regression was utilized to predict the effect of teachers' anxiety on their performance. This table reflected the value of R-square that use to indicate the variance of the dependent variable. According to the aforementioned table, there exists $18 \%$ variance in teachers' performance (dependent variable) with the reference of variation accounted in the teachers' anxiety (independent variable). Whereas $\mathrm{F}=74.933, \mathrm{p}<.005$, provide the evidence for fitness of model.

Table 3: Regression's coefficient indicating Effect of Teachers' Anxiety on Their Performance

\begin{tabular}{|l|l|l|l|l|l|}
\hline Model & \multicolumn{2}{|l|}{ Unstandardized Coefficients } & $\begin{array}{l}\text { Standardized } \\
\text { Coefficients }\end{array}$ & $\mathrm{t}$ & Sig. \\
\hline & $\mathrm{B}$ & Std. Error & Beta & & \\
\hline Performance & 6.310 & .123 & & 51.352 & .000 \\
\hline Leadership & -.404 & .047 & -.428 & 8.656 & .000 \\
\hline
\end{tabular}

Table 3 reflects the value of the coefficient of the independent variable (teachers' anxiety) against the dependent variable (teachers' performance). Beta value $=-.428, \mathrm{p}<.005$ indicated that teachers' performance is highly effected by teachers' anxiety, but the direction of this effect is inverse. Which provides the evidence to reject the null hypothesis? 
Normal distribution of data presented through the utilization of histogram along with this P-P and scatter plots represented to show the linear relationship, which is given below:

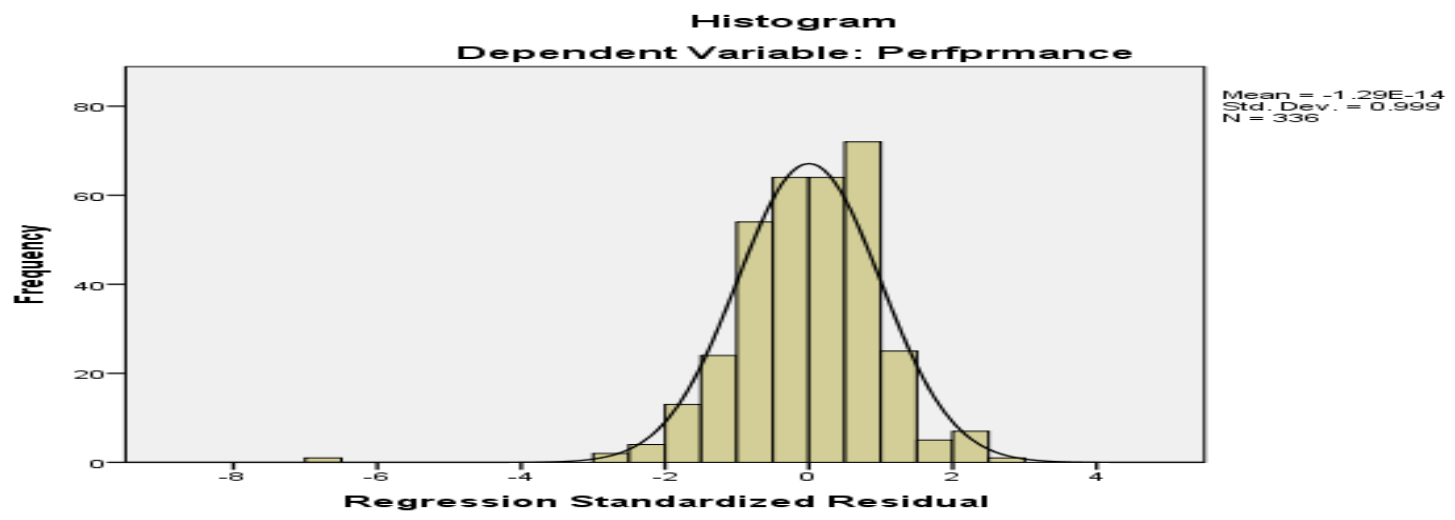

Figure: 1 Histogram of Teachers' Performance

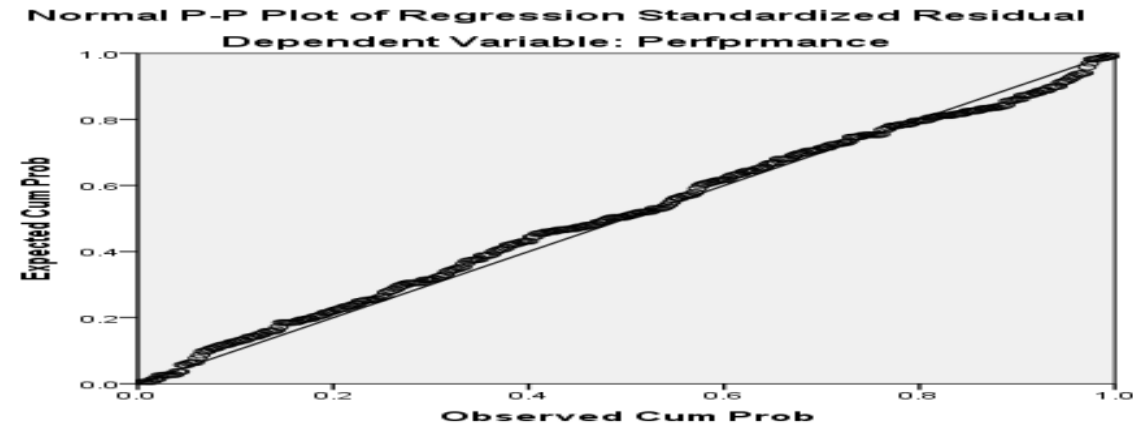

Figure: 2 P-P plot of Teachers' Performance

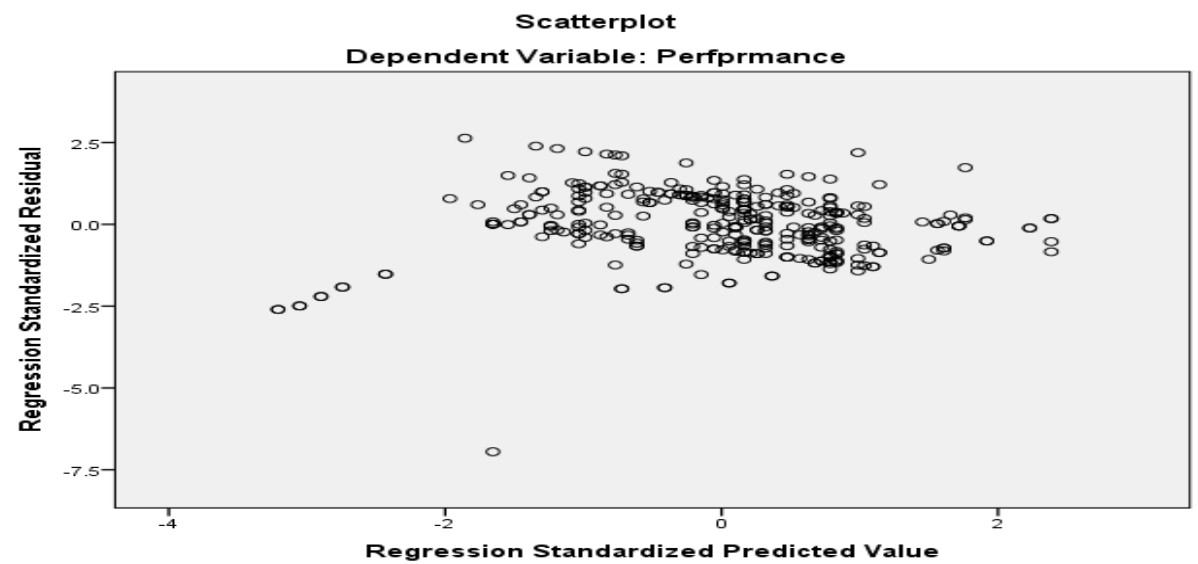

Figure: 3 Scatter plot of Teachers' Performance

Results presented in figure 1 reflect the histogram, indicating that the data is normally distributed. In the same pattern, figure 2 is about the P-P plot that highlighted the existence of a linear relationship. Similarly, in figure 3 no set pattern is observed that pointed out homoscedasticity.

\section{Conclusion and Discussion}

There are multiple factors that indicate language anxiety and low performance. The teachers' interaction is one of them. If the teacher him/herself is anxious, it will affect the students' academic achievement too. The aforementioned findings prove as a guideline to conclude the results that there 
exists a negative, moderate as well as significant correlation between teachers' anxiety and their performance. There is very limited relevant literature available on the said topic. Only two studies were found that highlighted the existence of a correlation between teachers' anxiety and performance. One of them was carried out in 2015 in Taiwan, whereas the other study was conducted in 2017 by considering the communication skills of Asian university teachers. The results of the current study are consistent with these two previous studies, (Khan, Khan, Zia-Ul-Islam, \& Khan 2017; Liu, 2015). They concluded that teachers' performance has been influenced by their language anxiety.

\section{Recommendations}

By considering the importance of teachers' anxiety on the teachers as well as students' performance it is recommended that FGEI's $(\mathrm{C} / \mathrm{G})$ focus on organizing the workshop on a regular basis regarding English speaking. Where teachers can have the opportunity to take part in different activities arranged to promote their English speaking proficiency. There should be seminars propagating about the strategies to cope with language anxiety.

\section{References}

Alqahtani, S. M. (2019). The impact of language anxiety on efl learners' proficiency: case study of university of jeddah. Adyala Journal, 844-864.

Asrar, D. Z., Tariq, N., \& Rashid, H. (2018). The Impact of Communication Between Teachers and Students: A Case Study of the Faculty of Management Sciences, University of Karachi, Pakistan. European Scientific Journal, 32-39.

Bee, S. B. (2012). The Impact of Teachers' Communication Skills on Teaching: Reflections of Pre-service Teachers on their Communication Strengths and Weaknesses. Humanising language teaching.

Buchmann, C., \& McDaniel, A. (2008). Gender Inequalities in Education. The annual review of sociology, 319-337. Retrieved January 2, 2018, from file://E:/Data/Research\%2oWork/Article\%2oppts/Article\%2oF\%2ogender\%2oBias/Gender\% 2oBias\%2021-12-18/Articles/buchmann2008.pdf

Chapman, A. (2019, january 2). Critical multicultural pavilion research room. Retrieved from Edchange: http://www.edchange.org/multicultural/papers/genderbias.html

Ehindero. (2000). What our student say about how we teach. education Studies, 1-9.

FGEI's. (2015, 9 17). Mission. Retrieved 9 17, 2015, from Fg educational institutions (c/g) directorate rawalpindi: http://www.fgei-cg.gov.pk/

Frawley, T. (2005). Gender Bias in the Classroom: Current Controversies and Implications for Teachers. Childhood Education, 81, 221-228.

GEM. (2019, 1 2). World education blog. Retrieved from Global education monitoring report: https:/gemreportunesco.wordpress.com/2016/10/o4/education-leading-for-gender-equality/

Guskey, T. R. (2000). Evaluating professional development. United States of America: Corwin Press Inc. A Sage Publication Company Thousand Oaks, California.

Hismanoglu, M. (2013). Foreign language anxiety of English language teacher candidates: A sample from Turkey. Procedia - Social and Behavioral Sciences, 930-937.

Horwitz, E. K., Horwitz, M. B., \& Cope, J. (1986). Foreign Language Classroom Anxiety. The Modern Language Journal, 125-132.

Jawad, Z. A., \& Al-Obaydi, L. H. (2015). Investigating the effect of language anxiety on student-teachers' oral performance. 8th Scientific Conference of the College of Education for Human Science/University of Diyala/ 2015. Diyala: University of Diyala.

Khan, A., \& Khan, D. S. (2017). Communication Skills of a Teacher and Its Role in the Development of the Students' Academic Success. Journal of Education and Practice, 18-21.

Khan, A., Khan, D. S., Zia-Ul-Islam, S., \& Khan, M. (2017). Communication Skills of a Teacher and Its 
Role in the Development of the Students' Academic Success. Journal of Education and Practice , 18-21.

Liu, H.-j. (2015). A Comparative Study of Foreign Language Anxiety and Motivation of Academic- and Vocational-Track High School Students. English Language Teaching, 193-204.

Loy, K. J. (2006). Kevin John Loy. (Unpublished Doctoral Thesis) The Ohio State University.

MacIntyre, \& Gregersen. (2012). The Role of Language Anxiety and Other Emotions in Language. Psychology for Language Learning. Retrieved from http://dx.doi.org/10.1057/9781137032829.0012

Obiunu, J. J. (2013). The Effect of Gender Sensitivity on Discrimination among Secondary School Students. Journal of Emerging Trends in Educational Research and Policy Studies, 888-894. $\begin{array}{llll}\text { Retrieved January 2, 2019, from } & \text { 2, }\end{array}$ https://pdfs.semanticscholar.org/e15c/4do9544cea2b91b4416e5370e7a93d6b3856.pdf

Reay, D. (2001). 'Spice Girls', 'Nice Girls', 'Girlies', and 'Tomboys': gender discourses, girls' cultures and femininities in the primary classroom. Gender and Education2, 153-166. Retrieved January 2, 2019, from file://E:/Data/Research\%2oWork/Article\%2oppts/Article\%20F\%2ogender\%2oBias/Gender\% 2oBias\%2021-12-18/Articles/reay2001.pdf

Tepeh, I. (2016). Language Anxiety: teachers' and learners perspectives. University of Zagreb (Unpublished Doctoral Thesis).

Tuncer, M. (2015). Effect of Foreign Language Classroom Anxiety on Turkish University Students' Academic Achievement in Foreign Language Learning. Journal of Education and Training Studies, 14-19.

UKFIET. (2019, January 2). Global education monitoring report. Retrieved from World education blog: https://gemreportunesco.wordpress.com/2017/o9/14/who-is-responsible-for-ensuring-genderequality-in-education/

UNESCO. (2019, January 2). United Nations Educational, Scientific and Cultural Organization. Retrieved from https://en.unesco.org/themes/education-and-gender-equality

UNICEF. (2019, January 2). Gender equality in primary and secondary education. Retrieved from UNICEF: https://www.unicef.org/rosa/what-we-do/education/gender-equality-primary-andsecondary-education

Wikipedia. (2019, January 2). Sex differences in education. Retrieved from Wikipedia: https://en.wikipedia.org/wiki/Sex_differences_in_education

Zulfiqar, M. S. (2016). Teachers' perceptions about in-service trainnig at federal government educational institutions (cantts/garrisons). Lahore: University of Education, Lahore (Unpublished MPhil Thesis). 